Original article

Paediatrics Today 2014;10(1):8-13

DOI $10.5457 / \mathrm{p} 2005-114.83$

\title{
CLINICAL CHARACTERISTICS AND MODALITY OF SURGICAL TREATMENT OF PEDIATRIC NEUROEPITHELIAL TUMORS
}

\author{
Hakija BEČULIĆ ${ }^{1}$, Harun BRKIĆ 2 , Mirsad HODŽIĆ ${ }^{2}$, Rasim SKOMORAC ${ }^{1}$, Aldin JUSIĆ ${ }^{1}$, \\ Alma MEKIĆ-ABAZOVIĆ ${ }^{3}$, Senad DERVIŠEVIĆ́ ${ }^{4}$, Lejla BEČULIĆ ${ }^{3}$
}

\begin{abstract}
${ }^{1}$ Department of Neurosurgery, ${ }^{3}$ Department of Oncology, Haemathology and

Radiotherapy and ${ }^{4}$ Department of Surgery, Cantonal Hospital Zenica, Zenica,

Bosnia and Herzegovina; ${ }^{2}$ Departments of Neurosurgery, University Clinical Hospital Tuzla, Tuzla, Bosnia and Herzegovina
\end{abstract}

Corresponding author:

Hakija Bečulić

Department of Neurosurgery

Cantonal Hospital Zenica

Crkvice 67,

72000 Zenica, Bosna i Hercegovina dr_beculichakija@hotmail.com

Tel.: + 38732405133

Fax.: + 38732405534

Received: November 2, 2013

Accepted: December 27, 2013

Copyright (C) 2014 by University Clinical Hospital Tuzla. E-mail for permission to publish: paediatricstoday@ukctuzla.ba
Objective - To analyze the clinical and histological characteristics, as well as to evaluate the results of surgical treatment of pediatric neuroepithelial tumors. Patients and methods - A retrospective study was conducted, including 40 pediatric patients surgically treated at the Clinic of Neurosurgery, University Clinical Hospital Tuzla in the period 2002-2012. During the study we formed groups and the analysis was conducted by age, gender, clinical signs, histopathologic types and type of surgical treatment. The results are presented in tables and expressed by relative values. Results - Neuroepithlial tumors are more common in male patients. There was no statistically significant difference in distribution of neuroepithelial tumors $\left(\chi^{2}=0.400 ; p=0.527\right)$ related to supratentorial and infratentorial localization. Infratentorial neuroepithelial tumors are most common at a younger age $(\mathrm{F}=6.516$; $\mathrm{p}=0.015)$. Increased intracranial pressure and seizures are the most common initial presentation of neuroepithelial tumors $\left(\chi^{2}=0.022\right.$; $\mathrm{p}=0.882)$. There was no statistically significant difference between types of surgical resection and localization of the tumor. Usually we performed total resection $\left(\chi^{2}=0.246 ; \mathrm{p}=0.620\right)$. There was a statistically significant difference in tumor grade regarding supratentorial and infratentorial localizations $(\mathrm{p}=0.013)$. Infratentorial tumors are higher grade $\left(\chi^{2}=5.495 ; p=0.019\right)$. Conclusion - The most common initial presentations of neuroepithelial tumors are increased intracranial pressure and seizures. Infratentorial tumors are higher grade. The most common initial treatment of neuroepithelial tumors is radical surgical resection.

Key words: Pediatric neuroepithelial tumors - Clinical characteristics - Surgical treatment.

\section{Introduction}

Pediatric intracranial tumors are the second most common form of cancer in the pediatric population (1). The incidence of pediatric brain tumors is about 2-5/100 000. Neuroepithelial tumors are the most common types of brain tumors in pediatric patients (2-4). About $50-60 \%$ of pediatric intracra- nial tumors are infratentorial (4). The most common histological types are: meduloblastomas, pilocitic astrocytomas and malignant gliomas (2, 4).

Neuroepithelial tumors represent a large group of intracranial tumors, having different histological and immunohistochemical characteristics, different grades and localiza- 
tions, and they occur in all age groups. Some histological forms and predominant localizations are more specific for pediatric patients as well as meduloblastomas, which are exclusively localized in the posterior cranial fossa, and pilocitic astrocitomas, which are usually localized in the posterior cranial fossa and in the hypothalamic region (2-6). The clinical presentation of neuroepithelial tumors depends on the location and could be specific for some types of tumors. The most common clinical signs of pediatric neuroepithelial tumors are increased intracranial pressure, focal disturbances, seizures, personality changes, and cranial nerve palsy. Clinical signs of infratentorial tumors include signs of increased intracranial pressure, vermian and hemicerebellar syndromes (4).

The aim of this research was to investigate the clinical and histological characteristics, as well as modalities of surgical treatment of pediatric neurepithelial tumors.

\section{Patients and methods}

This article consists of a retrospective study including 40 pediatric patients surgically treated at the Clinic of Neurosurgery, University Clinical Hospital Tuzla in the period from 2002 to 2012. During the study we formed groups according to age, gender, clinical signs, histopathologic types and type of surgical treatment. Of the total number of patients, there were $21(52.5 \%)$ males and 19 $(47.5 \%)$ females. Mean age was $11.14 \pm 3.92$ (males) and 10.21 \pm 3.92 (females), respectively ( $\mathrm{p}=0.502)$.

All patients had histologically diagnosed intracranial neuroepithelial tumors. In this research we used the files of patients, results of histopathological analysis, and records of magnetic resonance and computed tomography scans. The research was conducted with the approval of the ethics committee of the University Clinical Hospital Tuzla. The pa- tients with additional brain lesions were excluded.

\section{Statistical analysis}

The results are presented in tables. The results are expressed by relative values. We used the following methods of descriptive statistics: ANOVA comparisons, Chi-square test $\left(\chi^{2}\right)$ and $\mathrm{p}$-test. The level of statistical significance was $\mathrm{p}<0.05$.

\section{Results}

In this study, we presented 22 patients with infratentorial, and 18 patients with supratentorial tumors. The mean age of patients with supratentorial neuroepithelial tumors was $12: 50 \pm 3.5$ years and the mean age of patients with infratentorial tumors was $10.70 \pm 4.30$ years. There was no statistical significant difference in the age of patients in relation to tumor localization. Also our research showed a higher incidence of pediatric neuroepithelial tumors in males $(52.5 \%)$ compared to females $(47.5 \%)$. This incidence is slightly increased in some histological forms of neuroepitehelial tumors such as meduloblastomas. Our research showed that infratentorial tumors are more common in younger patients $(\mathrm{F}=6.516 ; \mathrm{p}=0.015)$.

The most frequent clinical signs were increased intracranial pressure in 28 or $70 \%$ and seizures in 9 or $22.5 \%$. Focal neurologic signs (in 1 or $2.5 \%$ ) and cranial nerve palsy (in 2 or $5.0 \%$ ) were rare. There was no statistical significant difference in the clinical presentation between supratentorial and infratentorial tumors $\left(\chi^{2}=0.022 ; \mathrm{p}=0.882\right)$.

The neurological signs of paediatric neuroepithelial tumors are presented in Table 1.

Among neurological signs the most frequent were: cerebellar ataxia (35\%), positive Romberg test $(27.5 \%)$ and nistagmus $(22.5 \%)$, without any difference between supratentorial and infratentorial tumors. 
Table 1 Neurological signs of pediatric neuroepithelial tumors

\begin{tabular}{|c|c|c|c|c|c|c|}
\hline \multirow{2}{*}{ Neurological signs } & & \multicolumn{2}{|c|}{ Localization of tumors } & \multirow{3}{*}{ Total } & \multirow{3}{*}{$\chi 2$ test } & \multirow{3}{*}{$\mathrm{p}$} \\
\hline & & Supratentorial & Infratentorial & & & \\
\hline & & & & & & \\
\hline \multirow{2}{*}{ Hemiparesis } & No & $18(100.0)$ & $17(77.3)$ & $35(87.5)$ & \multirow[t]{2}{*}{4.558} & \multirow[t]{2}{*}{0.040} \\
\hline & Yes & - & $5(22.7)$ & $5(12.5)$ & & \\
\hline \multirow{2}{*}{ Cranial nerve palsies } & No & $15(83.3)$ & $19(86.4)$ & $34(85.0)$ & \multirow[t]{2}{*}{0.070} & \multirow[t]{2}{*}{0.565} \\
\hline & Yes & $3(16.7)$ & $3(13.6)$ & $6(15.0)$ & & \\
\hline \multirow{2}{*}{ Visual disturbances } & No & $16(88.9)$ & $21(95.5)$ & $37(92.5)$ & \multirow[t]{2}{*}{0.600} & \multirow[t]{2}{*}{0.423} \\
\hline & Yes & $2(11.1)$ & $1(4.5)$ & $3(7.5)$ & & \\
\hline \multirow{2}{*}{ Neurological deficits } & No & $13(72.2)$ & $18(81.8)$ & $31(77.5)$ & \multirow[t]{2}{*}{0.510} & \multirow[t]{2}{*}{0.364} \\
\hline & Yes & $8(44.4)$ & $6(27.3)$ & $14(35.0)$ & & \\
\hline \multirow{2}{*}{ Nistagmus } & No & $15(83.3)$ & $16(72.7)$ & $31(77.5)$ & \multirow[t]{2}{*}{0.623} & \multirow[t]{2}{*}{0.341} \\
\hline & Yes & $3(16.7)$ & $6(27.3)$ & $9(22.5)$ & & \\
\hline \multirow{2}{*}{ Positive Romberg sign } & No & $13(72.2)$ & $16(72.7)$ & $29(72.5)$ & \multirow[t]{2}{*}{0.001} & \multirow[t]{2}{*}{0.623} \\
\hline & Yes & $5(27.8)$ & $6(27.3)$ & $11(27.5)$ & & \\
\hline \multirow{2}{*}{ Ataxia } & No & $13(72.2)$ & $18(81.8)$ & $31(77.5)$ & \multirow[t]{2}{*}{0.510} & \multirow[t]{2}{*}{0.36} \\
\hline & Yes & $5(27.8)$ & $4(18.2)$ & $9(22.5)$ & & \\
\hline \multirow{2}{*}{ Endocrine disturbances } & No & $18(100.0)$ & $21(95.5)$ & $39(97.5)$ & \multirow[t]{2}{*}{0.818} & \multirow[t]{2}{*}{0.550} \\
\hline & Yes & - & $1(4.5)$ & $1(2.5)$ & & \\
\hline \multirow{2}{*}{ Parinaud sign } & No & $18(100.0)$ & $21(95.5)$ & $39(97.5)$ & \multirow[t]{2}{*}{0.818} & \multirow[t]{2}{*}{0.550} \\
\hline & Yes & $0(0.0)$ & $1(4.5)$ & $1(2.5)$ & & \\
\hline
\end{tabular}

Table 2 Pathohistological diagnosis, localization and grade of neuroepithelial tumors

\begin{tabular}{|c|c|c|c|c|c|}
\hline Localization of tumors & $\begin{array}{l}\text { Grade } 1 \\
(\mathrm{n})\end{array}$ & $\begin{array}{l}\text { Grade } 2 \\
\text { (n) }\end{array}$ & $\begin{array}{l}\text { Grade } 3 \\
\text { (n) }\end{array}$ & $\begin{array}{l}\text { Grade } 4 \\
\text { (n) }\end{array}$ & $\begin{array}{l}\text { Total } \\
\text { (n) }\end{array}$ \\
\hline \multicolumn{6}{|l|}{ Supratentorial } \\
\hline Pilocitic astrocitomas & 2 & - & 0 & 0 & 2 \\
\hline Gangliogliomas & - & 5 & - & - & 5 \\
\hline Diffuse astrocitomas & - & 5 & - & - & 5 \\
\hline Glioblastoma multiforme & - & - & - & 3 & 3 \\
\hline Ependimomas & - & 2 & - & - & 2 \\
\hline Subependimal giant cell tumors & 1 & - & - & - & 1 \\
\hline Total & 3 & 12 & - & 3 & 18 \\
\hline \multicolumn{6}{|l|}{ Infratentorial } \\
\hline Pilocitic astrocitomas & 3 & - & - & - & 3 \\
\hline Diffuse astrocitomas & - & 4 & - & - & 4 \\
\hline Ependimom & - & 1 & - & - & 1 \\
\hline Oligodendrogliomas & - & 2 & - & - & 2 \\
\hline Meduloblastomas & - & - & - & 11 & 11 \\
\hline Anaplastic astrocitomas & - & - & 1 & - & 1 \\
\hline Total & 3 & 7 & 1 & 11 & 22 \\
\hline
\end{tabular}


The localization of neuroepithelial tumors, according to pathohistological diagnosis and their grade, are presented in Table 2.

The most common types of neuroepithelial tumors in the supratentorial compartment $(n=12)$ were grade 2 tumors, but in the infratentorial compartment $(\mathrm{n}=11)$ they were grade 4 tumors. Meduloblastoma was the most common type of grade 4 tumor. We registered only 3 cases with glioblastoma (grade 4), all in the supratentorial compartment. The chi-square test showed a statistically significant difference in grade and histological diagnosis $\left(\chi^{2}=5.495 ; p=0.019\right)$. Patients with infratentorial tumors had histopathologic diagnosis with a poorer prognosis.

The mean ages of patients in relation to tumor grade are presented in Table 3 .

There is no statistical significant difference in the ages of patients in relation to tumor grade $(\mathrm{F}=1.007 ; \mathrm{p}=0.401)$.

Types of surgical resection in relation to the localization are shown in Table 4.

There is no statistically significant difference in type of resection in relation to

\begin{tabular}{lll}
$\begin{array}{l}\text { Table } 3 \text { Mean age of patients in relation to tumor } \\
\text { grade }\end{array}$ \\
\hline Grade & $\mathrm{n}$ & Age (years; $\bar{X}_{ \pm} \mathrm{SD}$ \\
\hline 1 & 6 & $7.66 \pm 4.04$ \\
2 & 19 & $10.80 \pm 4.07$ \\
3 & 1 & 16.00 \\
3 & 14 & $10.81 \pm 4.62$ \\
\hline Total & 40 & $10.70 \pm 4.30$ \\
\hline
\end{tabular}

Table 4 Types of surgical resection in relation to the localization

\begin{tabular}{|c|c|c|c|}
\hline \multirow{2}{*}{$\begin{array}{l}\text { Type of } \\
\text { surgical } \\
\text { resection }\end{array}$} & \multicolumn{2}{|l|}{ Localization } & \multirow{2}{*}{$\begin{array}{l}\text { Total } \\
\text { n }(\%)\end{array}$} \\
\hline & $\begin{array}{l}\text { Supratentorial } \\
\mathrm{n}(\%)\end{array}$ & $\begin{array}{l}\text { Infratentorial } \\
\mathrm{n}(\%)\end{array}$ & \\
\hline Partial & $5(27.8)$ & 3 (13.6) & $8(20.0)$ \\
\hline Total & $9(50.0)$ & $15(68.2)$ & $24(60.0)$ \\
\hline Biopsy & $4(22.2)$ & $4(18.2)$ & $8(20.0)$ \\
\hline Total & $18(100.0)$ & $22(100.0)$ & $40(100.0)$ \\
\hline
\end{tabular}

the localization of the tumors $(\chi 2=0.246$; $\mathrm{p}=0.620)$. The most common type of surgical treatment was total resection.

\section{Discussion}

Pediatric intracranial tumors are the second most common cancer in this population and account for about $20 \%$ of all tumors in childhood $(5,6)$. There is a nearly equal distribution between the supratentorial and infratentorial compartments. Supratentorial tumors are often seen in children younger than 2 years, but supratentorial tumors are dominant in 3-10 years period. The incidence is equalized after 10 years of age (5-7). The incidence of pediatric neuroepithelial tumors is 2-5/100 000 children. Neuroepithelial tumors represent a large group of intracranial tumors, different histological and immunohistochemical characteristics, different grades and localizations, which occur in all age groups $(5,6)$.

Many articles indicate the clinical specificities of pediatric neuroepithelial tumors compared to other non-neurological diseases, making their identification easier (6-8). In our retrospective study we analyzed the clinical and histological characteristics of pediatric neuroepithelial tumors, as well as modalities of surgical treatment. The precise statistical analysis showed that there was no significant difference in tumor distribution by age groups. Other studies showed similar results (6-9). Infratentorial neuroepithelial tumors are most common in younger patients, which also correlates with the literature (9-11).

There is no statistical difference in initial presentation of neuroepithelial tumors in relation to supra or infratentorial localizations. Increased intracranial pressure was the most common clinical manifestation. It was registered in 28 cases. The second most common clinical sign was seizure ( 9 cases), seen only in supratentorial tumors. Cranial nerve palsy 
was registered in two cases, and focal neurological sign registered in one case. These results correspond to those from the literature $(9,10)$.

The most common neurological deficits were cerebellar ataxia and nistagmus, which is understandable since the majority of neuroepithelial tumors were located infratentorially. There was no difference in compartmental distribution of neuroepithelial tumors in patients presenting with hemiparesis as a neurological deficit or in patients without any neurological deficit. Generally, the compartmental localization does not imply the initial and neurological presentation of tumors. These results correspond to those from the literature (10-14).

Concerning the level of malignancy and pathohistological form, grade 1 and grade 4 were the most frequent. Low grade gliomas (grade 2) were the predominant forms of tumors in the supratentorial compartment (grade 2), while high grade gliomas (grade 4) were predominant in the infratentorial compartment, which is statistically significant. The two most common pathohistological forms of neurepithelial tumors were diffuse astrocytomas (grade 2) and medulloblastomas (grade 4). There is no statistically difference in the age of patient in relation to tumor grade. These results are the same as in the literature (15-21).

Surgery is the main modality of treatment of neuroepithalial tumors. As adjuvant therapy we could apply radiotherapy and hemotherapy (grade 2 to grade 4) (5-7). Radical surgical resection is the method of choice in surgical treatment of neuroepithelial tumors, regardless of its localization. In our sample, $50 \%$ of supratentorial and $68 \%$ of infratentorial tumors were radically resected. Grade 1 tumors have a good prognosis and radical surgical resection completely cured these tumors. Grade 2 tumors have infiltrative growth and cannot be completely resected.
Overall survival with these tumors is 5 to 10 years. High grade neuroepithelial tumors have poor prognosis with survival of up to 5 years. Usually, high grade neuroepithelial tumors cannot be completely resected (10-13).

This difference comes from the pathohistological characteristics of neuroepitehlial tumors, because radical surgical resection enables better results from adjuvant therapy (14-20). Other methods of surgical treatment included partial surgical resection and biopsy without a statistical difference regarding compartmental distribution. The most common postoperative complications include progression of neurological deficit, new neurological deficit, bleeding, infection and liquorrhoea. Postoperative morbidity in patients with intracranial neuroepithelial tumors is about $69 \%$ and mortality is about $1 \%(19-21)$.

\section{Conclusion}

The most common initial presentations of neuroepithelial tumors are increased intracranial pressure and seizures. Infratentorial tumors are higher grade. The most common and most important modality of treatment of neuroepithelial tumors is radical surgical resection.

Authors' contributions: Conception and design: HB, $\mathrm{HB}$; Acquisition, analysis and interpretation of data: $\mathrm{HB}, \mathrm{HB}, \mathrm{MH}$, RS; Drafting the article AJ, AMA; Revising it critically for important intellectual content: $\mathrm{HB}, \mathrm{MH}, \mathrm{SD}, \mathrm{LB}$.

Conflict of interest: The authors declares that they have no conflict of interest.

\section{References}

1. El-Zein R, Minn AY, Wrensch M, Bondy ML. Epidemiology of Brain Tumors. In: De Monte F, Gilbert MR, Mahajan A, McCutcheon IE, Buzdar AU, Freedman RS, editors. Tumors of Brain and Spine. Houston: Springer; 2007. p. 252-266. 
2. Akalan N. Intracranial tumors in childhood. In: Sindou M, editor. Practical Handbook of Neurosurgery from Leading Neurosurgeons. Wien-New York: Springer; 2009. p. 542-57.

3. Nasir S, Jamila B, Khaleeq S. A Retrospective Study of Primary Brain Tumors in Children under 14 Years of Age at PIMS, Islamabad. Asian Pacific J Cancer Prev. 2010;11:1225-7.

4. Rengachary SS, Ellenbogen RG. Principles of Neurosurgery, 2nd. Philadelphia: Elsevier Mosby, 2005:429-741.

5. Stevenson KL. Pediatric brain tumors. J Neurosci. 2004;1:10-20

6. Oghaki H. Epidemiology of Brain Tumors. Methods Mol Biol. 2009;472:323-42.

7. Kacar A, Paker I, Akcoren Z, Guer S, Kale G, Orhan D, et al. Solid tumors in Turkish children: a multicenter study. World J Pediatr. 2013;9:25-31.

8. Buetov PC, Smirniotopoulos JG, Done S. Congenital Brain Tumors: A Review of 45 Cases. AJNR. 1990;11:793-9.

9. Fangusaro J. Pediatric high grade glioma: a review and update on tumor clinical characteristics and biology. Frontiers in Oncology. 2012;2:2-10.

10. Duffner P, Horowitz ME, Krischer JP, Burger PC, Cohen ME, Sanford RA, et al. The treatment of mlignat brain tumors in infants and very young children: An update of the Pediatric Oncology Group experience. Neuro-oncology. 1999;152-61.

11. Edgar MA, Rosenblum MK. The Differential Diagnosis of Central Nervous System Tumors. Arch Pathol Lab Med. 2008;132:500-9.

12. Cbern JJ, Rao G, Lang FF. Medulloblastoma. In: Winn HR, editor. Youmans Neurosurgical Surgery. Philadelphia: Elsevier Saunders; 1996. p. 2570-92.

13. Bloom HJ, Glees J, Bell J, Ashley SE, Gorman C. The treatment and long-term prognosis of chil- dren with intracranial tumors: A study of 610 cases, 1950-1981. Int J Radiat Oncol Biol Phys. $1990 ; 18: 723-45$

14. Balter-Seri J, Mor C, Shuper A. Cure of recurrent medulloblastoma: the contribution of surgical resection at relapse. Cancer. 1997;79:1241-7.

15. Neervort FW, Ouwerkerk WJR, Folkersma H, Kaspers GJL, Wandertop WP. Surgical morbidity and mortality of pediatric brain tumors: a single center audit. Child Nerv Syst. 2010;26:1583-92.

16. Fried I, Hawkins C, Scheinemann K, Tsangaris E, Hesselson L, Bartles U, et al. Favorable Outcome With Conservative Treatment for Children With Low Grade Brainstem Tumors. Pediatr Blood Cancer. 2012;58(4):556-60.

17. Hales RK, Wharam MD. Pediatric High-Grade Glioma: Clinical-, Treatment-related, and Biologic Prognostic Factors. EJCMO, 2012;4:23-9.

18. Myseros JS, Reigel DH. Intraventricular Tumors. In: McLone DG, editor. Pediatric neurosurgery: surgery of the developing nervous system. Philadelphia: W.B. Saunders Company; 2001. p. 755-6.

19. Rorke LB. Pathology of brain and spinal cord tumors. In: Choux M, Di Rocco C, Hockley AD, Walker ML, editors. Pediatric neurosurgery. London: Churchill Livingstone; 2003. p. 395-426.

20. Jakacki RI. Treatment strategies for high risk medulloblastoma and supratentorial primitive neuroectodermal tumors. Review of the literature. J Neurosurg. 2005;102:44-52.

21. Taylor RE, Bailey CC, Robinson K, Weston CL, Ellison D, Ironside J, et al. Results of a Randomized Study of Preiradiation Chemotherapy Versus Radiotherapy Alone for Nonmetastatic Medulloblastoma: The International Society of Paediatric Oncology/United Kingdom Children's Cancer Study Group PNET-3 Study. J Clin Oncol. 2003;21:1581-91. 